\title{
視覚障碍者街歩き支援ナビの誘導システムに関する研究*
}

\section{A Study of Navigation System for Visually Handicapped to Support Town Walk -Media and Messages for Guidance-}

内田敬** ・吉井芳聡 $* * *$

By Takashi UCHIDA** • Yoshiaki YOSHII***

\section{1. はじめに}

近年GPSを用いた位置特定技術の進歩により、歩行ナビ ゲーションは広く普及している。晴眼者はGPSの精度が悪 い場所であっても地図画面を見ることて解決して歩行出 来る。しかし画面を見ることの出来ない視覚障碍者は、 精度の悪い場所では誤った案内をされていることに気づ かず、道に迷う恐れがある。そこで細い路地や精度の悪 い巨大構造物付近は無線タグのような、GPSよりも精度が 保証されたもので、電波を受信することで案内を行う必 要がある。

また、街中に存在する広場や車道との区別がない歩道 などの、形状が複雑な場所は、GPSや無線タグを用いても 適切な案内を行うことが困難である。そのような場合は

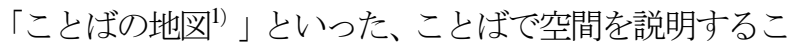
とで歩行の案内を行う必要がある。

このようにして、視覚障碍者が街歩きを楽しめるよう な歩行システムを作成することを本研究の目標とする。

これまでに著者らは、目的施設の検索・設定のシステ ムに関し、都心を対象とした目的地の施設カテゴリーの 分類を行い、利用者ニーズなどについて意見を得ている。 そこで本研究では、施設規模が小さくかつ多様であり、 案内に関しても複雑な内容が多く求められる郊外（地下 鉄駅周辺地区）を対象とした、施設の分類・歩行実験を 行う。

本研究では、

・郊外を対象地域とした施設の分類、

・歩行出来る信号のタイミングの誤差の許容範囲の確認、

・ことばの地図利用要素の優先順位の確立、

を目的とし、本稿では歩行実験・ヒアリングから得られ た結果、及びナビゲーションシステムの実用化をするに あたっての課題や提言について述べる。

*キーワーズ : GPS、ことばの地図、電子案内板、実験

**正員、博(工)、大阪市立大学大学院工学研究科

(大阪府大阪市住吉区杉本 3-3-138、TEL:06-6605-2731、

E-mail: uchida@civil.eng.osaka-cu.ac.jp)

***学生員、大阪市立大学大学院工学研究科 表-1＼cjkstart実験時に使用した音信号

\begin{tabular}{|c|c|c|c|}
\hline \multicolumn{2}{|c|}{ 指示方向 } & $\begin{array}{c}\text { 予告メッセージ } \\
\text { の有無 }\end{array}$ & 音信号 \\
\hline \multirow{6}{*}{$\begin{array}{l}\text { 基本 } \\
\text { 信号 }\end{array}$} & 直進 & 無 & Pi Pi Pi Pi \\
\hline & 右折 & 有 & Piii Pi Piii Pi \\
\hline & 左折 & 有 & Piii Pi Pi Piii Pi Pi \\
\hline & 戻れ & 無 & Piii Piii Piii Piii Piii Piii Piii Piii Piii \\
\hline & 警告 & $\begin{array}{ll}\text { 無 } \\
\end{array}$ & Pi Pi Pi Pi Pi Pi Pi Pi Pi Pi Pi Pi Pi Pi \\
\hline & ゴール & 無 & Pi Pi Piii Piii Piii ～Pi Pi Piii Piii Piii \\
\hline \multirow{2}{*}{$\begin{array}{l}\text { 音声 } \\
\text { 案内 }\end{array}$} & 右斜め & 無 & 右斜め方向 \\
\hline & 左斜め & $\begin{array}{ll}\text { 無 } \\
\end{array}$ & 左斜め方向 \\
\hline
\end{tabular}

\section{2. ナビシステムの特徵と検討課題}

\section{（1）ナビシステムの特徵}

本ナビゲーションシステムは視覚障碍者も利用出来る ものであり、普及している歩行ナビと同様に、飲食店や スーパーなどを目的地として設定し、街歩きを案内する。 案内は音信号とことばの地図を用い、情報端末は携帯電 話を使用し、骨伝導ヘッドフォンを通じて指示を出す。

なお本ナビゲーションは利用者の街歩きにおける歩行 を補助するものであり、危険回避を行うものではない。 そのため利用者の歩行安全性については普段と同様利用 者自身に委㸚るものとする。

ナビゲーションの流れとしては、駅などに設置されて いる電子案内板から行きたい目的地のカテゴリーを選択 し、携帯電話をかざす。かざすと携帯電話の目的地設定 のサイトに接続し、音声案内により目的地を設定すれば ナビゲーションを開始する。

歩行の案内としては、既往研究 2) 3) で得た単純な音信 号(表-1参照) と本研究で検討することばの地図を用いる。 歩行時の環境音聴取をできるだけ阻害しないために単純 な音信号による案内・誘導を基本とし、音信号のみでは 不十分な場面でことばの地図を用いる。ナビゲーション は既存システムのGPSで案内出来る範囲はGPSを利用し、 GPSでは精度が低いため案内が困難な範囲は無線タグを 設置し、携帯電話で電波を受信することで案内を行う。 しかし無線タグは場所によっては精度が低くなる場合が あることと、大量に使用すれば経費がかさむことが問題 となる。そこで、ことばにより空間の構成や歩行の方法 を説明するため、例え案内を出すタイミングの精度が低 
表-2＼cjkstart郊外での施設抽出内容

\begin{tabular}{|c|c|c|}
\hline 施設カテゴリー & 施設内容 & アイテム数 \\
\hline マンション & マンション・社宅・文化住宅など & 647 \\
\hline 会社・事務所 & 工務店・建築事務所・協同組合・労働組合など & 434 \\
\hline 商業施設 & $\begin{array}{l}\text { 飲食店・スーパー・商店・電気店など } \\
\end{array}$ & 366 \\
\hline 医療関係 & 病院・針众院・介護関係など & 110 \\
\hline 学校関係 & 小中高等学校・保育園・学習塾・図書館など & 81 \\
\hline ビル & $\begin{array}{c}\text { 貸ビル・ホテルなど } \\
\end{array}$ & 81 \\
\hline 寺社・教会 & 寺・神社・教会・宗教・書院など & 50 \\
\hline 駐車場 & 駐車場・貸ガレージ・貸倉庫など & 42 \\
\hline 市役所関係 & 市役所・コミュニティ会館・福祉会館など & 28 \\
\hline 長居公園施設 & $\begin{array}{c}\text { 長居競技場・長居植物園など } \\
\end{array}$ & 18 \\
\hline その他 & 分別不能であるもの & 218 \\
\hline
\end{tabular}

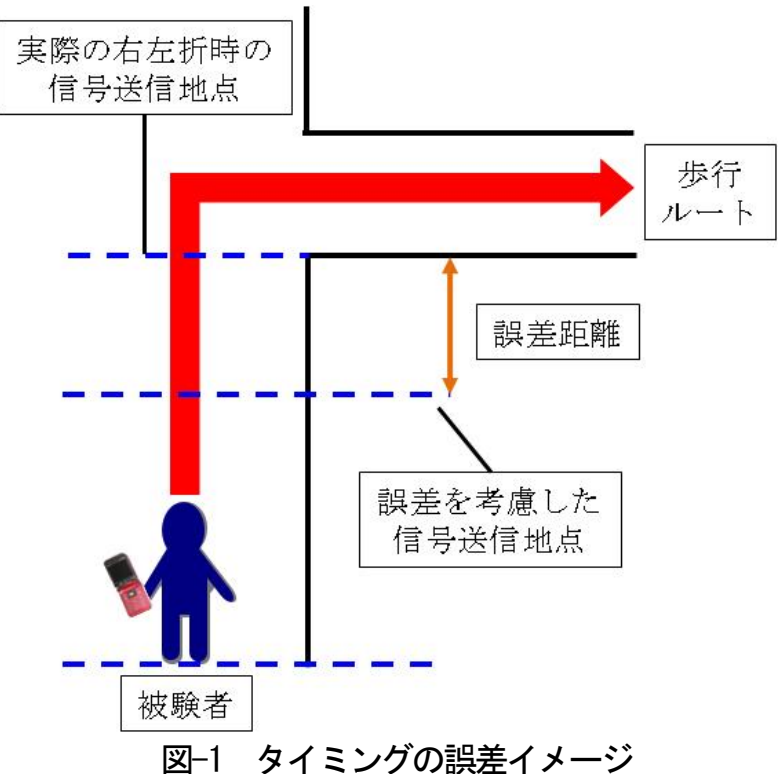

いとしても、歩行を行うことが可能であることばの地図 を用いることとする。

(2) ナビシステムの検討課題

a）郊外における目的地施設の分類

目的地の施設は地域によって異なり、著者らは既に都 心(西梅田)での分類を行っている゙)。都心では特徴的な分 類として「地下街へのアクセス」「周辺の主要ビル」な どが成果として得られた。そこで課題としては、地域に より特徴があり、都心とは異なる郊外においてどのよう な分類がなされるかということが挙げられた。

これより本研究では、住宅地や大規模な公園、商店街 など郊外施設が多く存在する大阪市の長居地区を対象地 域に選定し、分類を行う。施設の分類に関しては、郊外 に存在する施設を対象に、「施設の存在数・需要の高さ」

「施設の特徵」に着目して評価を行い、郊外の施設分類 の基礎を作成した。そして電子地図データを用いて長居 地区の約2.4キロメートル四方の範囲に存在する施設を抽
表-3 長居を対象とした施設分類の重要度

\begin{tabular}{|c|c|c|c|}
\hline 重要度 & \multicolumn{2}{|c}{ 高 $\longleftrightarrow$ 低 } \\
\hline \hline \multirow{3}{*}{ 施設 } & 商店街 & トイレ & 公共機関 \\
\cline { 2 - 4 } & 長居公園 & 駅 & その他 \\
\cline { 2 - 4 } & グルメ・ショッピング & 宿泊 & \\
\hline
\end{tabular}

出し、施設分類基礎に従って具体分類を行った。表-2に 抽出した施設の内容、表-3に重要度順に並べた長居の分 類を示す。これを原案とし、分類に関しては被験者への ヒアリングから、作成した長居の分類が適切であるかの 確認、またナビシステムが実用化された際にどのような 場所で利用したいかといった利用者ニーズについて明ら かにする。

b）GPS と無線タグの利用範囲

GPSによる位置特定技術は地域や時刻、天候や周辺状況 により精度が変化する。本研究では長居公園歩行実験の 歩行コースにてGPSの誤差実態を概略調查した。結果とし て天候条件の違いであれば大差はないが、利用した大半 の場所で約1 5メートルの誤差が見られ、大きな構造物 周辺では平均30メートルの誤差が生じた。30メートルの 誤差では視覚障碍者が歩行出来ないことは明らかである が、視覚障碍者はどの程度の䛊差であれば歩行可能であ るかについて確認する必要がある。この許容範囲を確認 し、それよりも精度の低い場所については無線タグの案 内に切り替えるなどの対応を考えねばならない。歩行実 験では右左折時に被験者に送る音信号のタイミングをず らし(図-1参照)、歩行出来る範囲の確認を行う。

\section{c）ことばの地図利用要素の優先順位}

ことばの地図の作成は要素の抽出、要素の評価、案内 文の作成といった順で行う。そこで必要となるのは要素 の評価を行うための指標である。そこで本研究では指標 として案内が必要な要素の優先順位を考慮する。 
表 -5 実験概要

\begin{tabular}{|c|c|c|c|}
\hline \multicolumn{2}{|r|}{ 実験場所 } & 長居公園 & 大阪市立大学 \\
\hline \multicolumn{2}{|r|}{ 実験日程 } & 2009年 $10 \cdot 11$ 月 & 2010年1月 \\
\hline \multirow{3}{*}{$\begin{array}{c}\text { 被験者 } \\
\text { 人数 }\end{array}$} & 全盲 & 20 & 23 \\
\hline & 弱視 & 4 & 8 \\
\hline & 計 & 24 & 32 \\
\hline \multirow{3}{*}{\multicolumn{2}{|c|}{ 実験目的 }} & $\begin{array}{l}\text { 施設カテゴリー分類の適切さをヒアリ } \\
\text { シグから確認 }\end{array}$ & - \\
\hline & & $\begin{array}{l}\text { タイミングに䛊差が生じても歩行は可 } \\
\text { 能であるかを確認する }\end{array}$ & $\begin{array}{l}\text { 長居公園歩行実験でのタイミングより } \\
\text { も誤差の距離を延ばすことで歩行は可 } \\
\text { 能であるかを確認する }\end{array}$ \\
\hline & & $\begin{array}{l}\text { ことばの地図として必要・不要な要 } \\
\text { 素、重要・重要でない要素、不適切な } \\
\text { ことばなどがいかをヒアリングから } \\
\text { 確認する }\end{array}$ & $\begin{array}{l}\text { 作成した優先順位が適切であるか、要 } \\
\text { 素を絞りヒアングから確認する }\end{array}$ \\
\hline \multirow{3}{*}{$\begin{array}{l}\text { 実験 } \\
\text { タスク }\end{array}$} & 歩行コース数 & $\begin{array}{c}3 \text { בコース } \\
\end{array}$ & 3 3コース \\
\hline & 距離 $(\mathrm{m})$ & 1,250 & 200 \\
\hline & 所要時間 & 40分 & 5分 \\
\hline \multicolumn{2}{|c|}{ ヒアリング方法 } & 個人 & グループ \\
\hline
\end{tabular}

表-4 ことばの地図の要素内容

\begin{tabular}{|c|c|c|c|c|}
\hline 要素 & 内容 1 & 内容 2 & 内容 3 & 内容 4 \\
\hline 空間説明 & 場所情報 & 視覚情報 & 聴覚情報 & 嗅覚情報 \\
\hline 歩道形状 & 歩車分離 & 段差 & 道幅 & 縁石 \\
\hline 点字ブロック & 位置 & 形状 & 消失 & - \\
\hline 歩行方法 & \multicolumn{4}{|c|}{ 複雑な道などのたどり方を案内 } \\
\hline 設置物 & 花壇 & モニュメント & 柵 & 車止め \\
\hline 周辺環境 & 植栽 & 休㮩スペース & 芝生 & 河川 \\
\hline 変動環境 & 通行人 & 駐輪 & 駐車 & 露店 \\
\hline ランドマーク & 建物 & 橋 & タワー & 噴水 \\
\hline 転落転倒危険性箇所 & 溝 & 橋 & 階段 & 段差 \\
\hline
\end{tabular}

※「転落転倒危険性箇所」は白杖歩行を対象とする。

歩行実験では、歩行中にことばの地図を再生すること で被験者の歩行を案内する。そして、実験歩行後にヒア リングで要素の重要性について意見をもらうことで利用 者ニーズを把握し、優先順位を決める。また、ことばの 地図において、言葉として理解が出来ない・空間把握と して理解が出来ない表現などはないかについても確認す る。ことばの地図について、概要と要素に分けて以下に 記す。

1）ことばの地図の概要

ことばの地図とは、「中心に噴水のある円形の広場」 の様に、音信号だけでは案内が不十分なものをことばに より案内するものであり、GPSや無線タグの精度では不十 分な箇所についても、空間の説明を行うことで利用者を 誘導する案内である。ことばの地図により利用者は空間 の認識が出来、歩行の案内につながるかを実験にて確認 する。

2）ことばの地図の要素

ことばの地図の要素とは、歩行空間を構成する要素の ことであり、空間から抜き出すと表-4のような要素が考
えられる。これらの要素を、歩行中にこ とばの地図で全て案内することは困難 なため、実験から優先順位を定めて必要 な要素を案内する。

\section{3. 歩行実験概要}

(1) 歩行実験の目的

表-5に歩行実験の概要を示す。 2007 ・ 2008年の歩行実験は都心を中心に行わ れてきた。都心は「騒がしくて音信号が 聞こえない」「通行人との錯綜で方向性を失う」といっ た理由から道を逸脱する可能性が高いという特徵を有す るが、実験によって音信号のみで案内が可能であること が確認出来ている゙)。本研究では郊外を対象とした歩行実 験を行うが、郊外は都心に比べて広く空間を利用してお り、車道と歩道の区別がつきにくい場所や円形で空間を 把握しにくい広場などの不定形な場所が多く存在する。

このような「歩きにくい場所が多い」という状況下にお いて、どのようなことばの地図で案内することが適切で あるかを実験で確認する。

本研究における歩行実験の目的は、被験者へのヒアリ ングから研究内容について有意義な意見をもらうことで ある。ヒアリングはナビを利用していることを想像して 意見をもらうのではなく、実際利用してもらうことで現 実的な意見が欲しい。そのため歩行実験では被験者に単 独歩行をしてもらい、骨伝導ヘッドフォンを装着するこ とで環境音も聞き取れるようにし、実用時に近い状態で 行う。また歩行実験は被験者個々により結果が異なるた め、障碍程度や年齢、性別などが様々な被験者で行う。 


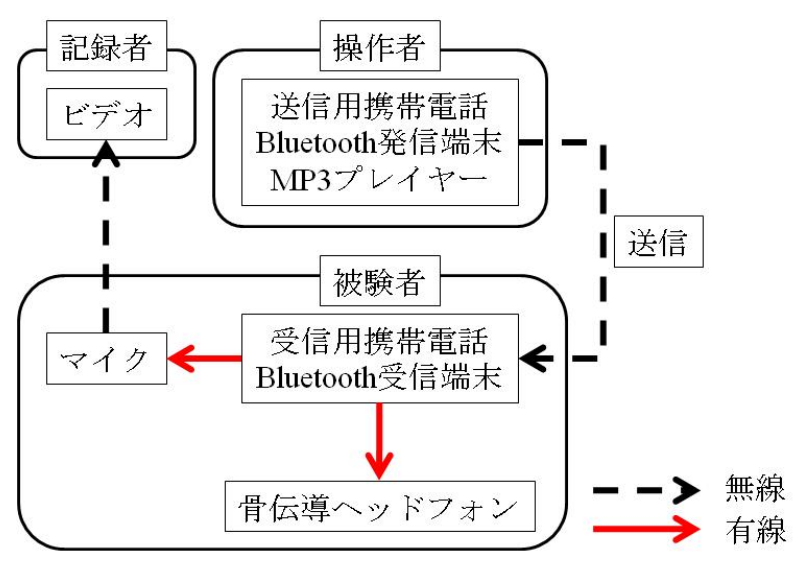

図-2 使用機器と送受信の関係

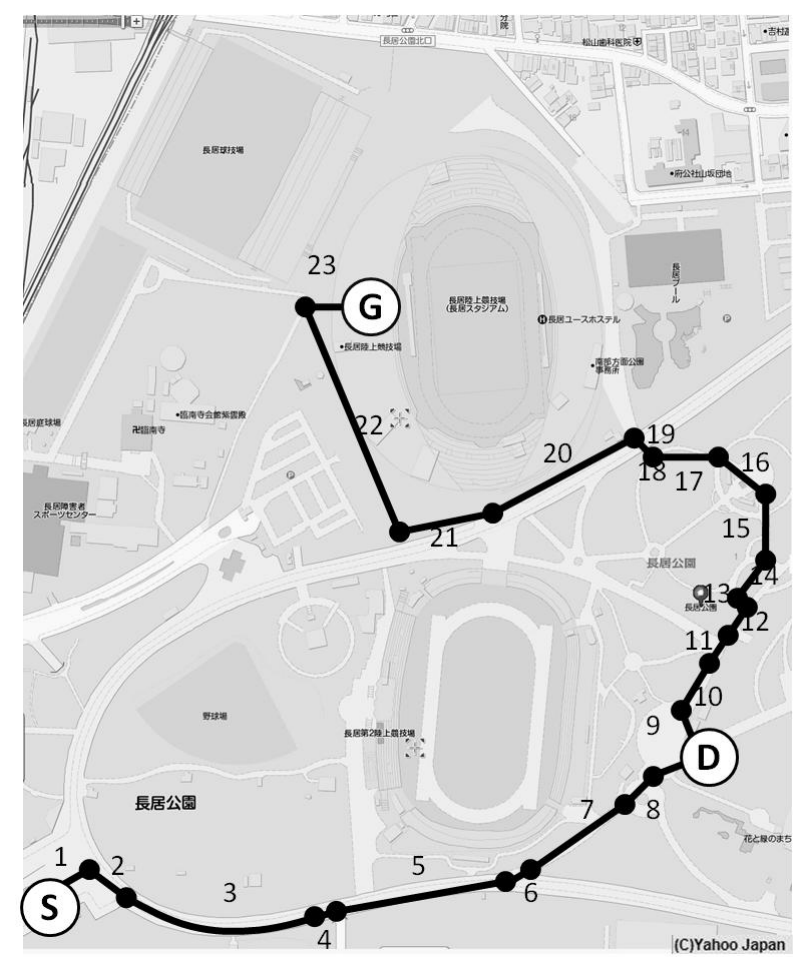

図-3＼cjkstart歩行実験コ一ス（長居公園）

実験時の歩行挙動はビデオ撮影で記録した。撮影結果 は、歩行コースでの被験者の逸脱が多い箇所についての 原因、案内方法の改善、そしてタイミングの誤差の許容 範囲について、被験者の歩行行動を分析し、確認するこ とを目的とする。

\section{（2）実験機器}

歩行実験では先述したように実用に近い状態で行うた め、被験者の所持する機器は携帯電話と骨伝導ヘッドフ オン、記録用マイクと無線受信機となっている。図-2に 実験機器と信号の送受信の関係を示寸。

また、案内する音信号やことばの地図については、音 質を落とし、速さも標準の速さのみで案内しており、最 低限度の状態で実験を行うことで、どのような状況下で も案内が可能であるかの確認を行っている。 表-6＼cjkstart長居での施設カテゴリ一分類

\begin{tabular}{|c|c|}
\hline 電子案内板（第零階層） & WEBページ（第一階層） \\
\hline \multirow{2}{*}{ 商店街 } & 長居商店街 \\
\hline & 鶴厅丘商店街 \\
\hline \multirow{5}{*}{ 長居公園 } & 長居公園入口 \\
\hline & 運動施設 \\
\hline & 事務所 \\
\hline & 博物館・植物園 \\
\hline & 売店 \\
\hline \multirow{2}{*}{ グルメ・ショッピング } & グルメ \\
\hline & ショッピング \\
\hline \multirow{2}{*}{ トイレ } & 男子・女子トイレ \\
\hline & 身体障害者用卜イレ \\
\hline \multirow{3}{*}{ 交通 } & 電車 \\
\hline & バス \\
\hline & タクシー \\
\hline \multirow{2}{*}{ 宿泊 } & ホテル \\
\hline & ユースホステル \\
\hline \multirow{6}{*}{ 生活 } & 医療 \\
\hline & 教育 \\
\hline & 金融 \\
\hline & 区役所 \\
\hline & 警察 \\
\hline & 消防 \\
\hline \multirow{5}{*}{ その他 } & オフィス \\
\hline & 娛楽 \\
\hline & 宗教 \\
\hline & 住まい \\
\hline & 美容 \\
\hline
\end{tabular}

\section{（3）実験の手順}

まず被験者に機器の装着や音信号の説明、音量調節を 行い、その後、設定した歩行コースを約40分歩行しても らった。タイミングのずれやことばの地図の詳細につい ては説明せず、最低限の導入説明でどこまで被験者は単 独歩行出来るかを確認した。コースについても目的地の みを案内し、詳細については説明せずに実験を行った。 ただし歩行中の音信号・ことばの地図の聞き逃しについ ては何度でも行えるものとした。これは実用時のメッセ ージリピートを模したからである。歩行が終わるとヒア リング会場に移動し、各被験者にヒアリングを行った。 実験中に撮影しているビデオ映像と音声は実験後に確認 し、考察を行った。

\section{4. 長居公園歩行実験}

\section{（1）実験の詳細}

2009年10・11月に視覚障碍者24名を対象に大阪市東住 吉区長居公園にて行った。歩行コースを図-3に示す。コ 一ス特徽としては、円形で噴水やベンチや植木がある広 場や、公園内の森の通路、陸上競技場前の幅が非常に広 い広場などがあり、空間が変化し、形状が複杂隹な場所が 
表-7ヒアリング結果（長居公園歩行実験）

\begin{tabular}{|c|c|c|c|c|}
\hline 区分 & 分かりにくい籄所 & 詳細 & 改善方法 & 付け足して欲しい案内 \\
\hline \multirow{6}{*}{$\begin{array}{l}\text { 前半 } \\
(10 / 24 \sim \\
10 / 27)\end{array}$} & 両端（りょうたん） & 聞いたことのない読み方 & 「りょうたん」ー「りょうはし」 & 形状が特殊（古いなど）な点字ブロック \\
\hline & 歩車分離歩道 & 専門用語のため語意不明 & 車道との境界に段差のある歩道 & 地面の材質による変化 \\
\hline & 円形状 & 形状の想像が出来ない & 状況により変化 & 危険な場所の詳細 \\
\hline & 植栽 & 専門用語のため語意不明 & 植え込み & 「点字ブロックなし」 \\
\hline & 流入部 & 専門用語のため語意不明 & 三叉路の右からの自転車に注意 & 「現在橋の中央地点」 \\
\hline & Eニュメント & 発音・語意が分からない & 発音を分かりやすく & \\
\hline \multirow{4}{*}{$\begin{array}{l}\text { 後半 } \\
(10 / 29 \sim \\
11 / 6)\end{array}$} & 点字ブロックなし & 「なし」の案内は不要 & 分かりやすい人が過半数のため維持 & 休㮩出来る場所の案内 \\
\hline & 道幅 & どこの幅か分からない & $\lceil$ 道幅 $\sim \mathrm{m}\rfloor \rightarrow$ 歩道 $\sim \mathrm{m}$ 、車道 $\sim \mathrm{m}\rfloor$ & 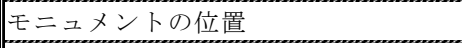 \\
\hline & 曲がりくねつた & 形状の想像が出来ない & 両端の縁石からはみ出さずに歩行 & \\
\hline & 円形状左カーブ & 形状の想像が出来ない & 左方向の緩やかなカーブ & \\
\hline
\end{tabular}

多い。路面もコンクリートや土、草地など様々な場所が あり、境界に縁石がある場所もない場所も存在寸る。ま た公園内のため曜日や時間帯によっては運動する人や自 転車で通行する人も多く、ことばの地図でも危険である ことを案内した。

ことばの地図は約3〜11秒の長さであり、案内の長さに より歩行中の煩わしさが生じる可能性があるため、長さ が適切であるかについて確認する。また、ことば・単語 で分かりにくい部分などはないかについても確認寸る。

(2) 実駼結果

a）郊外施設の分類の適切さ

郊外の施設の分類について、長居を対象とした分類が 適切かどうかをヒアリングした。結果として、追加して 欲しい施設 (タクシー乗り場) や内容が分からないカテ ゴリー名（公共機関）などが得られた。ヒアリング結果 から改善して作成した分類を表-6に示す。

また同時に得られた意見として、ナビが実用化した際 に利用したい場所については「買い物」「公園」といっ た、普段の生活の中で、行き慣れてはいるが一人では行 けない場所であった。今後はこのような利用者ニーズを 踏まえて分類として必須である施設について考慮してい く必要がある。

b）信号のタイミング誤差

信号のタイミング誤差について、今回歩行した被験者 21人中 5 人がタイミングのずれによりコースを逸脱した。 逸脱の原因は様々であり、白杖が縁石に当たったため別 の方向一向かい逸脱する、縁石を乗り越えて植栽の中に 入ることで逸脱するなどであった。ただし、いずれも電 波タグから送信することを前提に5メートル程度逸脱し た時点で「戻れ」信号を出すことで元のコースに戻るこ とが出来た。ずれの大きさは約1２メートルであり、事 前にタイミングのずれが生じる説明は行っていないこと から、説明なしという条件下でも1メートル前後であれば 「戻れ」信号の使用により歩行可能であると分かった。

しかしGPSは先述した通り約1〜 5メートルは大抵の場
所で誤差が生じるため、さらに大きな誤差での確認が必 要となる。そのため次段階の大阪市立大学歩行実験では、 タイミングをずらす距離を幾通りか試すことで、許容範 囲を明らかにすることとした。

c）ことばの地図

ことばの地図の要素に関するヒアリング結果とその改 善方法を表-7に示す。

歩行実験の前半では、表-7に示している「植栽（しょ くさい）の意味が分からない」といった聞き慣れないこ とば・単語があるという意見が多く得られた。これらの 読み方や案内方法を改善し、改善されたことばの地図を 用いて後半実験を行うと、改善箇所は問題ないという意 見を得た。後半は「曲がりくねった」といった形状の説 明を行っている案内で、全盲の被験者からどういった形 をしているか想像がつかないという意見を得た。こうい った場合は形状ではなく、「縁石に沿って歩行」といっ た歩行の方法を案内することで改善出来ると考えられる。

これらのことから、ここでは視覚障碍者の言語理解度 と、障碍程度による空間認知の関係について考察する。 視覚障碍者の言語理解度について、視覚障碍者は弱視や 途中失明で漢字を学んでいる人もいれば全く学んでいな い人もいる。漢字を学んでいない人は日本で広く用いら れている訓読みの言語の方が理解しや寸いと考えられる。 ただし、音読みであっても広く知られている言語に関し ては問題ない。また専門用語について、「歩車分離歩道」 といった語については視覚障碍者だけでなく、晴眼者に おいても分かりにくい語であるため、各分野の専門用語 は使用を避ける必要がある。障碍程度による空間認知の 関係について、先天盲（ものを見た記憶がない状態）の 障碍程度では、空間形状を示す言語を案内されても、ど ういった形状をしているのかが想像出来ない。そのため 形状を案内するのではなく、具体的な歩行方法を案内す る必要があると考えられる。

d）ことばの地図要素の優先順位

ヒアリングから被験者が重要だと考える要素を確認し、 
表-8 優先順位 (一次案)

\begin{tabular}{|c|c|c|}
\hline 優先順位 & \multicolumn{2}{|c|}{ 要素 } \\
\hline 1 & 歩行方法 & 転落転倒危険性箇所 \\
\hline 2 & 歩道形状 & 点字ブロック \\
\hline 3 & ランドマーク & 空間説明 \\
\hline 4 & 設置物 & 周辺環境 \\
\hline 5 & \multicolumn{2}{|c|}{ 変動環境 } \\
\hline
\end{tabular}

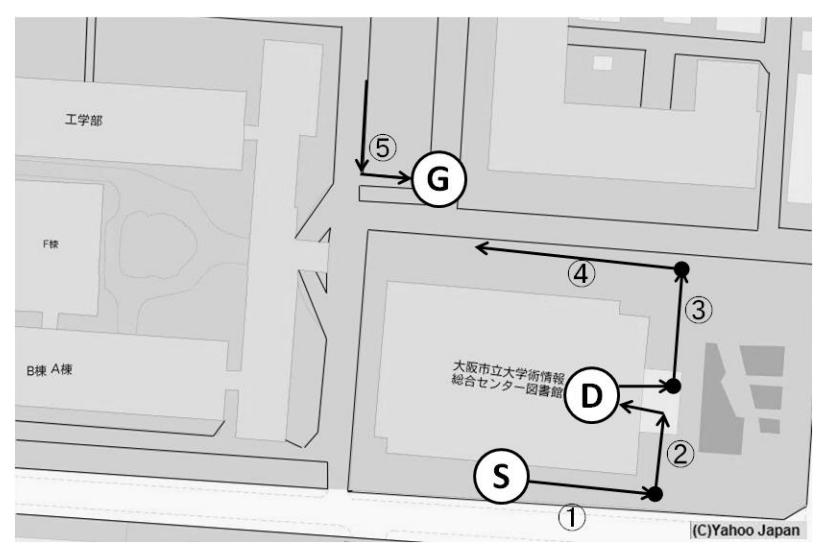

図-4＼cjkstart歩行実験コ一ス（大阪市立大学）

利用者ニーズを踏まえて優先順位の考察を行った。結果 を表-8に示す。

ヒアリングでは必ず必要な要素はどれかと質問してお り、結果として歩道形状・点字ブロック・転落転倒危険 性箇所という順に利用者ニーズが高いことが分かった。 実際ことばの地図として案内する際に特に重要と考えら れるものは、複雑な道の案内を行う歩行方法や、利用者 の安全に関わる転落転倒危険性箇所である。これらは利 用者ニーズと関係なく、案内しなければ歩行出来ない、 危険であるということから優先順位は高くなる。他の要 素についてはニーズと重要性の下に決定しており、変動 環境については日々変動するもの（駐車・駐輪や人など） を案内寸ることは難しいことから優先順位を低くしてい る。この優先順位について、大阪市立大学歩行実験にて 適切であるかの確認を行う。

また、案内の長さについては最長約13秒について、特 に煩わしさや、歩行に支障をきたすことはないとの意見 が得られた。

\section{5. 大阪市立大学歩行実験}

(1) 実験の詳細

2010年1月に視覚障碍者32名を対象に大阪市立大学に て行った。歩行コースを図-4に示す。歩行実験ではタイ ミングの誤差の許容範囲の確認、ヒアリングではことば の地図の要素の優先順位の適切さの確認に重点を置いて 行った。

コースの特徵としては、長居公園と比べれば空間的な

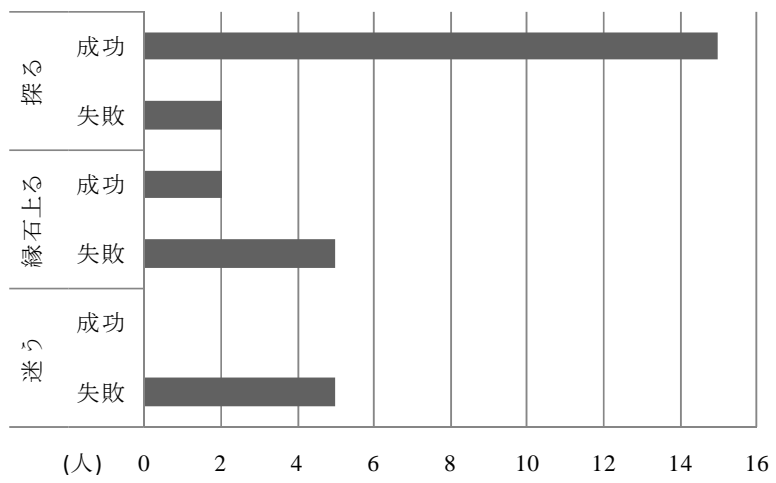

図-5 タイミング実験の行動累計と結果

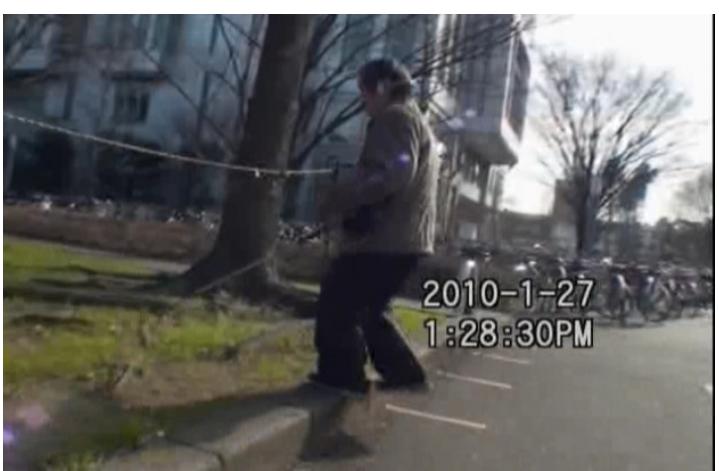

図-6 タイミング実験行動（縁石上る）

変化などは少なく、コースも短くなっている。一部駐輪 場があり、点字ブロック上にも駐輪が置かれている場所 があり、歩行には注意しなければならない。区間(3)は 間(2)と似た形状の場所で、点字ブロックが連続して敷設 されている。点字ブロックの案内の重要性を確かめるた め、区間(3)の点字ブロックの案内を除いた。区間(5)に ついてタイミングをずらして誤差の許容範囲を明らか にするため、縁石が敷設してある障害物のない単純な左 折のコースとした。

(2) 歩行実験結果

a) 誤差の許容範囲

音信号の送信タイミングをずらして歩行が出来たかに ついては、大半の被験者がタイミングをずらしても左折 することが出来た（32人中 25 人）。タイミングをずらし た距離は、音信号を出した時点で約4メートルのずれがあ り、縁石にたどり着いた距離は個々により異なって左折 地点の0〜4メートル手前であった。

図-5に示寸ように、タイミングをずらして左折が出来 なかった全盲の被験者の特徵としては、音信号を発信し た後、縁石を上りはするものの（図-6参照）、白杖で周 囲を探る行動をしていないと分かった。ヒアリングでは 事前にタイミングのずれがあることが分かっていれば曲 がることも出来た、という意見を得ている。このことか ら今回の約4メートルの誤差であれば、タイミングの誤差 
表-9 優先順位（改善案）

\begin{tabular}{|c|c|c|c|}
\hline \multirow{2}{*}{ 優先順位 } & \multicolumn{3}{|c|}{ 案内内容別要素 } \\
\hline & 安全性 & 歩行場所 & 周辺情報 \\
\hline 1 & 転落転倒危険性箇所 & 歩行方法 & \\
\hline 2 & \multicolumn{2}{|c|}{ 点字ブロック } & \\
\hline 3 & 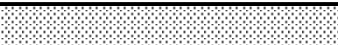 & \multicolumn{2}{|c|}{ 歩道形状 } \\
\hline 4 & & 空間説明 & ランドマーク \\
\hline \multirow{2}{*}{5} & & म०० & 路上設置物 \\
\hline & 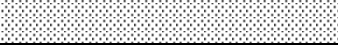 & 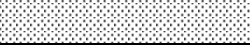 & 周辺環境 \\
\hline 6 & \multicolumn{3}{|c|}{ 変動環境 } \\
\hline
\end{tabular}

表-10 ことばの地図案内文（改善案）

\begin{tabular}{|c|c|c|c|c|c|}
\hline 歩行実験 & パターン & & & ことばの地図 & \\
\hline \multirow{3}{*}{$\begin{array}{l}\text { 長居公園 } \\
\text { 歩行実験 }\end{array}$} & $\mathrm{A}$ & 円形状の広場 & 中央に噴水あり & 点字ブロックに沿って円の左部分を歩行 & ベンチと植木が点在 \\
\hline & $\mathrm{B}$ & 円形状の広場 & 中央に噴水あり & 点字ブロックに沿って円の左部分を歩行 & - \\
\hline & $\mathrm{C}$ & 円形状の広場 & 中央に噴水あり & 円の左寄りの花壇に沿って歩行 & ベンチと植木が点在 \\
\hline \multirow{3}{*}{$\begin{array}{c}\text { 大阪市立大学 } \\
\text { 歩行実験 }\end{array}$} & $\mathrm{A}$ & 車道との境界に車止めのある歩道 & 幅は 3 メートル & $\begin{array}{c}\text { 左端に溝あり } \\
\end{array}$ & 左側に点字ブロックあり \\
\hline & $\mathrm{B}$ & 車道との境界に車止めのある歩道 & - & $\begin{array}{c}\text { 左端に溝あり } \\
\end{array}$ & 左側に点字ブロックあり \\
\hline & $\mathrm{C}$ & 車道との境界に車止めのある歩道 & 幅は3メートル & 左寄りに点字ブロックあり & 点字ブロックの左側に溝あり \\
\hline
\end{tabular}

を把握していれば白杖で探るため、歩行は可能であると 考えられる。なお、左折地点から 3.5 メトルまでの距離 で縁石にたどり着いていれば曲がれていることが分かっ ており、3.5メートルを超えれば迷う被験者が多くみられ た。迷う被験者に共通寸る点は白杖で探っていないこと であり、このことからも白杖で周りの状況を確かめるこ とは非常に重要であることが分かり、実用の際はユーザ 一に事前説明をする必要がある。

弱視の被験者についてはタイミングをずらしても迷う ことなく目視で左折地点を確認し、全員左折寸ることが 出来た。しかし弱視であるために、曲がり角が近接して 複数あるような場所では、もしタイミングがずれればど の道が正しいのかが判断出来ない。このような場合には 道を間違えれば「戻れ」信号で案内するといった対応が 考えられ、今後の課題として確認する必要がある。

\section{b) 優先順位の改善}

ヒアリングでは点字ブロックの必要性、溝・道幅・点 字ブロック・車止めといった要素の中で最も重要なもの と重要でないもの、駐輪場の案内の必要性について質問 し、優先順位の一次案が適切であるかを確認した。表-9 にヒアリング結果から改善を行った優先順位を示す。示 している要素についてはそれぞれ、要素がどのような内 容の案内をするのかについて分類を行っている。安全性 については最低限案内をしなければ危険につながる要素 の存在を案内する要素、歩行場所については歩行する場 所の説明を行う要素、周辺情報については歩行する場所 を構成する物体について案内を行う要素となっている。

ヒアリング結果は、点字ブロックの必要性については、 大半の被験者が案内は必要であると答えた。点字ブロッ クは視覚障碍者にとって正しい方向、そして安全性を示
しており、道案内に関しては必要性の高い要素であるこ とが分かった。また点字ブロックがない箇所も案内して 欲しいとの意見も得られた。内容としては「危険な箇所 では点字ブロックがないことを教えて欲しい」「点字ブ ロックがある道とない道に分かれていて点字ブロックの ない道に進年場合は教えて欲しい」といったものであり、 点字ブロックなしの案内は、歩行コースの環境などに合 わせて案内するか否かを考慮する必要がある。

要素の重要性について、最も重要な要素は「溝」とい う意見が多く、次いで点字ブロックとなった。「溝」は 転落転倒危険性箇所としてのみならず、点字ブロックの ない場所では方向を確認する役割を担うことが分かり、 より一層重要性が高いことが確認出来た。「道幅」に関 しては点字ブロックよりも重要ではないという意見が多 く得られた。「道幅」は3メートル程度のものであれば白 杖で探ることで把握することが可能なため、それ程重要 ではなく、それ以上になれば幅を把握出来ないため重要 となることが分かった。

駐輪場については、案内は必要という意見が大半であ った。もし点字ブロックが敷設されていたとしても駐輪 場は危険な場所のため案内が欲しいという意見も得られ、 重要性はかなり高いと考えられる。駐輪場は転落転倒危 険性籄所であり、優先順位は適切であるが、駅や店舗先 などの不法駐輪に関しては変動的であるため変動環境と して扱う必要がある。

この優先順位とヒアリング結果から、それぞれの歩行 実験で用いたことばの地図を改善したものを表-10に示 す。示していることばの地図は、「A : 存在する要素を全 て含む」「B：優先順位が低い要素を含まない」「C：案 内の言い回しを替えている」の3通りのパターンで分けて いる。このパターンについては、様々なパターンを用意 
することで、実用化の際に利用者が利用しやすい設定で 変えることが出来るようにすることを予定している。

\section{6. 実用化への提言と研究の課題}

本章ではナビゲーションを実用化するにあたり、必要 となると考えられる事項について述べる。

\section{（1）ことばの地図利用要素の事前調査}

ナビゲーションを実用化する際には、まず目的地まで のルートを探索する必要がある。そしてそれぞれのルー トに存在することばの地図の要素を調査しなければなら ない。ルートの探索については、複雑な場所が多いが短 いルート、単純な場所が多いが長いルート、危険な場所 が少ないルートなど候補が多くある中で、ユーザーが設 定出来る環境を整えるべきである。このように歩行ルー トについてはユーザーの立場から様々な条件を考慮し、 それぞれに合ったコースをいくつか調査することが望ま しい。

要素の調査に関しては、歩行ルート上の要素を全て調 查し、抽出することは困難であるため、必要な要素のみ を的確に抽出することが重要となる。そこで必要な要素 をまとめたチェックシートを作成しておくことが望まし い。空間を構成物がそれぞれの要素に含まれるかは異な る。例えば先述した「道幅」は、3メートルを基準に案内 に必要か不要かが変化し、「溝」は蓋があるかないかで 必要か不要かが変化する。このような場合を考慮した上 でチェックシートを作成する必要がある。

\section{（2）事前案内・設定の必要性}

歩行実験では事前説明をほとんどせず、音信号の簡単 な説明と歩行安全性を自身に委祆ることのみ説明した。

結果として図-7に示寸ように、音信号の確認については 大半の人が聞きなおすことなく歩行出来ており、多くて も4、5回確認する程度であった。なお音信号は、1被験者 あたりの全送信回数が平均約85回であるため、その内の5 回であれば確認回数としては多くはなく、すぐに覚える ことの出来る音であることが分かる。このように利用者 は最低限の案内さえ理解していれば歩行することが可能 であることは確認出来ている。一方で、スムーズに歩行 するためには事前案内が必要であり、ナビの特徵を利用 者が知っておく必要がある。

事前案内としては、ナビの使い方（操作方法・目的地 設定方法など）や目的地到着までの流れ、歩行の際の立 場（自身の安全性確保）、機器の不具合などが挙げられ る。その中でもGPSの誤差が生じることの認識は非常に重 要なものと考えられ、歩行実験の結果から分かるように、 ナビの案内のタイミングがずれることで迷う利用者は多

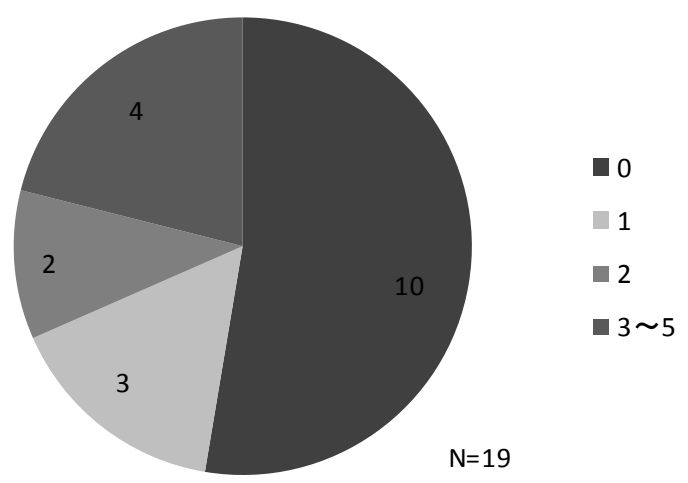

図-7 音信号確認回数（長居公園歩行実験）

くいるはずである。そこで白杖で探ることが出来るか出 来ないかの差は大きく、白杖で探る意識を持つには先述 したように事前に誤差が生じるため探る必要があること を案内する必要がある。

次に利便性を高めるものとして機器のユーザー設定が 挙げられる。利用者の好みに合わせ、流れる音声の速度 や音声の種類（性別）、ことばの地図の必要・不要、要 素の多い・少ない、といった設定が出来るようにする。 また、歩行コースの概要については、歩行する直前にお およそのコースの距離・コースの長さ・空間的な特徴な どを利用者の設定で案内出来るようにする。ヒアリング ではこのような歩行コースの情報が欲しいという意見が あり、この案内があることで歩行直前の歩行への心構え や、歩行中に目的地に近づいているという安心感につな がるものとなる。

このように利用者に任せる設定は数多くあり、これら は障碍程度や歩行技術など個々の特徴によっても変化す る。そのため利用者が設定できる範囲について、出来る 限り広く設定出来る環境を作り、個人に適した歩行が出 来るようにする必要がある。

\section{7. まとめ}

本研究では歩行実験とヒアリングから、郊外を対象と した施設の分類、ことばの地図利用要素の優先順位の決 定、音信号の送信タイミング誤差の許容範囲について明 らかにした。

音信号とことばの地図を用いて案内することで、利用 者がナビに歩行を案内されるのではなく、周辺の空間が どのように構成されているのかを想像しながら歩行出来 るようになった。また既存のGPSの精度は低い場所が多い が、本研究での音信号とことばの地図を用いることで、 多少の誤差はカバーすることが可能であろう。むしろGPS による位置特定を基本として、例えば、アプローチ部が 多数ある広場的通路など、視覚障碍者が歩く際に精度が 良くなければ歩行出来ない場所を明らかにし、そのよう 
な場所で無線タグを用いていく必要がある。

本ナビゲーションは道案内を行うものである。道案内 をスムーズに行うためには、利用者が案内に従って真っ すぐに歩くことが重要である。視覚障碍者は障碍程度や 歩行能力によっては真っすぐに歩くことも可能であるが、 それは一部であり横にそれてしまうのが大半である。そ の際に真っすぐ、あるいは道に沿って歩いている目安に なるのが点字ブロックである。点字ブロックに沿って歩 いていれば点字ブロックを見失ったり、障害物などで点 字ブロックから外れたりしない限り道に従って歩くこと が出来る。本研究で行った実験においても、点字ブロッ クを発見した被験者は、ほぼ全てが点字ブロックに頼っ た。しかし点字ブロックの現状としては、敷設が不十分 な場所や、通行人が点字ブロック上で立ち往生している、 駐輪がある、といった状態であり、歩行を妨げる要因と なっている。そのため、本ナビゲーションの実用化と共 に、こうした点字ブロックの適切な整備や、社会の点字 ブロックに対するマナ一向上などについても並行して取 り組んでいかなければならない。
本研究は平成21～23年度科学研究費補助金（基盤B, 21360247）の助成を受けて実施した。

参考文献

1）ITS(高度道路交通システム)社会実験調査 : 梅田ターミナル地 区移動支援実験報告書(概要版), 2002.3.

2）望月翼，内田敬 : 視覚障碍者ナビの基本指示に用いる音色と タイミングに関する実験，交通工学研究発表会論文報告集, pp.165-168, 2007.10.

3）望月翼, 内田敬, 吉井芳聡 : 視覚障碍者ナビにおける信号音 の種類及ひ使用可能環境に関する研究，土木計画学研究・講 演集，No.38，4 pp.(CD-ROM)，2008.11.

4）吉井芳聡，内田敬，望月翼，日野泰雄 : 視覚障碍者街歩き支 援ケイタイのユーザーインターフェイスに関する研究, 平成 20 年度土木学会関西支部年次学術講演会講演概要集, 2pp.(CD-ROM), 2008.5.

\section{視覚障碍者街歩き支援ナビの誘導システムに関する研究*}

内田敬**・吉井芳聡***

近年、GPSを位置特定に活用した晴眼者向けの歩行ナビゲーションが広く普及している。しかし位置特定技 術は精度が低く、案内は視覚障碍者がそのまま利用するには難しい状況である。本研究では音信号・ことばの 地図を用い、実用に近い状態で郊外を対象として視覚障碍者向けのナビを歩行体験してもらった。本稿では実 験とヒアリングから、郊外を対象とした施設の分類、タイミングの誤差の許容範囲、ことばの地図の要素の優 先順位についてそれぞれ明らかにし、ナビゲーションの実用化にあたつての提言を行う。

\section{A Study of Navigation System for Visually Handicapped to Support Town Walk -Media and Messages for Guidance-*}

By Takashi UCHIDA**·Yoshiaki YOSHII***

Recently, navigation systems for pedestrian are widespread with advancing positional specific technology, e.g. GPS.

However, the accuracy of a positional specific technology is after low, and even audio guide is difficult for visually handicapped people.

In the study, a navigation system for the visually handicapped was experienced by using the signal of sound and the verbal map in the condition similar to practical use. In this paper, the classification of facilities intended for suburbs, a margin for error of timing , and the priority level of the element of the verbal map are clarified from the experiment and hearing. Then, the proposal of the practical use of the navigation is discussed. 